\title{
Access to the US Federal Courts: Only Interested Parties Need Apply?
}

\author{
Barry Hough*
}

In the progress towards a comprehensive system of administrative law withering fire has been directed at the doctrine of locus standi as traditionally expounded. The dichotomy forged by the civil law between public and private rights, the former belonging to, and finding their protection in, the Crown as parens patriae, and the latter belonging to the right-holder, is simplistic and inadequate in a pluralistic society in which there exist "numerous groups, communities and collectivities" 'between the individual and the State. A system which regards a remedy as a correlative of a right or interest is somewhat paradoxical; for in public interest litigation the court is expected to have regard to, and to protect, the public interest, but must do so at the instance of an individual affected in his private capacity. Applied most strictly, this tends to undermine the rule of law since, if no suitably qualified challenger will present himself as plaintiff, the unlawful conduct of the defendant may continue without a remedy. ${ }^{2}$ Moreover, administrative law has developed somewhat illogically to a point at which it cannot protect the meritorious but unqualified litigant in cases such as Gouriet v. Union of Post Office Workers, ${ }^{3}$ but it can offer protection to the unmeritorious litigant affected by an administrative decision which is vitiated by procedural defects. ${ }^{4}$

No-one has recognised the deficiencies of the traditional system more than Lord Denning whose work in this field is well recorded. For him there could be no barrier raised against the individual who brought a bona fide complaint to the notice of the court. An individual with a prima facie case could overcome the threshold issue. For example, in $R$. v. Paddington Valuation-Officer, ex p. Peachey Property Corporation Ltd. ${ }^{5}$ he stated:

* Of the School of Law, University of Buckingham.

1. Capalletti, "Vindicating the Public Interest through the Courts: A Comparativist's Contribution", Access to Justice 3 (1979) 514, 521. See, e.g., the Sierra Club in Sierra Club v. Morton 405 U.S. 727 (1972),

2. Gouriet v. Union of Post Office Workers [1978] A.C. 435 provides an example in which this may have been the case.

3. Supra n.2.

4. In cases where there has been a failure of natural justice an unmeritorious applicant may still be granted relief: Ridge v. Baldwin [1964] A.C. 40. See also, per Lord Denning, in Annamunthodo v. Oilfelds Workers' Trade Union [1961] A.C. 945, 956.

5. [1966] I Q.B. 380, 400. 
"I do not think grievances are to be measured in pounds, shillings and pence. If a ratepayer or other person finds his name included in a valuation list which is invalid, he is entitled to come to court to have it quashed. He is not to be put off by the plea that he has suffered no damage." (Emphasis supplied)

Hence Mr Blackburn, whose injury was fundamentally no greater than that of the community at large, may have had standing to challenge the prosecution policy of the Metropolitan police ${ }^{6}$ and, later, the unlawful manner in which the Greater London Council was exercising its powers of film censorship; ${ }^{7}$ and $\mathrm{Mr} \mathrm{McWhirter}$ had his day in court to challenge the proposed broadcasting of an allegedly pornographic film notwithstanding that the Attorney-General had refused his fiat to relator proceedings. ${ }^{8}$ As is well known, the House of Lords adhered to a more traditional exposition of the standing rules; ${ }^{9}$ but there are clear signs that, following the introduction of R.S.C. Order 53, a less restrictive approach has been adopted based on the "sufficient interest" formula. ${ }^{10}$

It is striking that, whilst Lord Denning was engaged in re-fashioning English law, similar developments could be traced in other common law jurisdictions and, in particular, the United States. The expansion of the law of standing in Federal law has largely been the work of the Supreme Court. Arguably, this trend reached its zenith in U.S. v. SCRAP, ${ }^{11}$ after which concern was expressed that further progress would allow the judiciary, almost by self-invitation, to step beyond the jurisdiction to which it is confined by Art. III of the Federal Constitution. This notwithstanding, there exists a line of authority which places a fundamental reinterpretation upon Art. III thereby posing new questions touching upon the proper role of the courts in the settlement of disputes. The resulting tensions in the law are not dissimilar to those which sparked between the Court of Appeal and the House of Lords whilst Lord Denning held office as Master of the Rolls. Developments in the federal courts constitute a most valuable study, and the purpose of the present article is to examine and evaluate these as an instructive approach to similar problems which have faced our own courts.

It will be shown how, in Federal law, the law of standing developed away from a 'strict legal rights' theory to one where access to court was based primarily upon the challenger having suffered some "injury in fact"; how that formula was expanded to the point where "any identifiable trifle" could suffice to generate locus standi; how subsequently the concept of "injury in fact" was limited by the adoption of strict rules requiring that the "injury" be sufficiently proximate to the action challenged; how, in spite of the recent narrowing of the standing concept,

\section{6. [1968] 2 Q.B. 118.}

7. R. v. Greater London Council, ex p. Blackbum [1976] 1 W.L.R. 550.

8. R. v. Independent Broadcasting Authority, ex P. McWhinter [1973] Q.B. 629.

9. Gouriet v. Union of Post Office Workers, supra n.2.

10. I.R.C. v. National Federation of Self-Employed and Small Businesses Ltd. [1982] A.C. 617; R. v. Hammersmith E Fulham Borough Council, exp. People before Profit [1981] f.P.L. 869.

11. 412 U.S. 669 (1973). 
there remains a line of authority which holds that rules of standing based upon the self-interest of the litigants in the outcome of the litigation are not strictly warranted by Art. III of the Federal Constitution; and how it is that in certain circumstances any plaintiff may have access to court notwithstanding his own lack of interest in the outcome, provided that the court, on hearing him, can be assured that he will present every view which would have been advanced had the right-holders themselves been before the court. It is not impossible that, at some future date, the abandonment of the traditional "injury-standing" philosophy will be based on an expansion of this line of authority.

\section{Standing in the U.S. Federal Courts}

Article III of the United States Constitution places a fundamental limitation upon the competence of the Federal courts: their jurisdiction is limited to "cases" or "controversies". ${ }^{12}$ It has been stated that this rests upon "a single basic idea - the idea of separation of powers." 13 The orthodox interpretation of Art. III is that it requires a live dispute between self-interested parties. ${ }^{14}$ It follows that the courts have never pronounced upon "abstract", "conjectural" or "hypothetical" issues; ${ }^{15}$ for example the Supreme Court has declined to advise the Executive on the "construction of treaties, law of nations, and the laws of the United States." ${ }^{16}$ Art. III has been held to prohibit both the litigation of third-party rights, ${ }^{17}$ and

\section{Article III, Section 2}

1. The judicial power shall extend to all cases, in law and equity, arising under this Constitution, the laws of the United States, and treaties made, or which shall be made, under their authority; to all cases affecting ambassadors, other public ministers, and consuls; to all cases of admiralty and maritime jurisdiction; to controversies between two or more States; between a State and citizens of another State; between citizens of different States; between citizens of the same State claiming lands under grants of different States, and between a State, or the citizens thereof, and foreign States, citizens or subjects.

13. Allen v. Wright 104 S.Ct. 3315, 3325 (1984) per Justice O'Connor delivering the judgment of the Supreme Court.

14. If the plaintiff's claim is settled, or he loses his interest in the matter, after the filing of the action, he will lose a legally cognizable interest in the matter which is then "mooted". The courts will generally decline to rule on a matter which has been "mooted", unless the facts are "capable of repetition, yet evading review" in a similar matter. For example, if the plaintiff's interest in the matter is that she is pregnant and denied an abortion by virtue of State laws which she alleges are unconstitutional, she would lose her interest upon the birth of the child. If the court held that her claim were "mooted" by the birth of the child it would effectively deny the plaintiff all chance of appellate review of her case. In the normal process an appeal could not be heard within the normal gestation period of 266 days. Thus, a strict application of the "mootness" doctrine would effectively deny her, and every other pregnant challenger, the opportunity to contest the constitutionality of the statute on appeal with the result that the constitutionality of the statute would always evade review in the superior courts: see Roe v. Wade 410 U.S. 113,125 (1975).

15. Allen v. Wrighl, supra n.13.

16. Twenty-nine questions concerning the construction of a pending treaty were submitted to the Supreme Court for its opinion by President Washington in 1793. The Court declined to consider the matter since no live dispute within Art. III was involved. The matter, in the absence of a "case" or "controversy", was merely advisory and outside the function of the judicial branch of the State.

17. Tileston v. Ullman 318 U.S. 44 (1943). But this seems to admit of exceptions: see Singleton v. Wulf 966 S.Ct. 2868 (1976). 
generalized grievances. ${ }^{18}$ The requirement that the plaintiff should demonstrate a "personal stake in the proceedings" 19 is seen as a "core component" of Art. III and derives "directly from the Constitution." 20 Although Art. III is not explicit about the nature of the interest which the plaintiff must demonstrate in the proceedings, and indeed is silent as to whether or not any interest need be shown, nonetheless the courts have felt able to require that an interest must be demonstrated by the litigant and to determine the nature of that interest having regard to the policy function of the law of standing and prevailing social attitudes.

Originally, the "cases" or "controversies" principle was construed so as to limit the judicial role to the settlement of private disputes. Judicial control of administrative action could only proceed at the instance of an individual directly affected in his private legal rights. Tennessee Electric Power Co. v. Tennessee Valley Authority is a leading decision in which the "legal interest" test was advanced. It was there held that standing pre-supposed "... that the right invaded is a legal right. One of property, one arising out of contract, one protected against tortious invasion, or one founded on statute which confers a privilege." ${ }^{21}$

Fundamentally, the "legal interest" test denied the individual any protection of non-economic values, the aesthetic, conservational and recreational. ${ }^{22}$ It also. limited the scope for potential challenge to what would generally be a small class of persons affected in their legal rights. The supposed justification for such a rule was that it prevented a multitude of claims arising out of one unlawful act ${ }^{23}$ and yet would ensure the vindication of the rule of law because the greatest incentive to challenge unlawful conduct lay with those economically affected.

However, experience in the United States demonstrated that the fear of judicial inundation could not, by itself, justify continued adherence to such a narrow standing formula as the "legal interest" test. Individuals do not trifle with the courts. In recognition of this, and in the limited context of the Michigan Environmental Protection Act 1970, the standing barrier was removed since it was felt that if anti-pollution controls were to be effective the private individual must have a central role in the enforcement of the legislation. The Act enabled any individual to bring proceedings against anyone else to ensure the protection of the air, water, and natural resources of the State. Significantly, Michigan is highly

18. Schlesinger v. Reservists to Stop the War 418 U.S. 208 (1974).

19. Baker v. Carr 369 U.S. 186, 204 (1962).

20. Per O'Connor J. in Allen v. Wright, supra n.13. See per Bark J. (concurring) in Vander Jagt v. O'Neil 699 F. 2d. 1166, 1178-1179: "All of the doctrines that cluster about Art. III - not only standing, but mootness, ripenness, political question and the like - relate in part . . to an idea which is more than an intuition, but less than a rigorous and explicit theory, about the constitutional and prudential limits to the powers of an unelected judiciary in our kind of government."

21. 306 U.S. $118,137-138$ (1938).

22. In Association of Data Processing v. Camp 397 U.S. 150, 154 (1970), the Supreme Court emphasized that standing could be based upon a threat to these kinds of interests as well as economic loss.

23. This was a policy which was, perhaps, imported into Federal law from England. An early statement appears in William's Case, 5 Co. Rep. 72b, 73a. 
industrialized with extensive mining and manufacturing undertakings within its boundaries, especially around Detroit, all of which could pollute four of the five Great Lakes which lie within the State. However, the courts were not swamped with claims. In the years following the introduction of the Act, and notwithstanding the immense potential for litigation, only a comparatively small number of claims were brought under it each year. ${ }^{24}$ The clear lesson was that the restrictive doctrine of standing could not be justified as a protection for the courts from numerous claims arising out of a single unlawful act. ${ }^{25}$ The Supreme Court responded by abandoning the "legal interest" test in favour of a more extensive standing formula. In Association of Data Processing v. Camp ${ }^{26}$ it was held that access to Federal courts would be available to a plaintiff who could demonstrate that:

"... the challenged action has caused him injury in fact, economic or otherwise." 27

and additionally that:

"... the interest sought to be protected is arguably within the zone of interest

to be protected or regulated by the statute or constitutional guarantee in question." 28

A bi-partite test for standing was thereby introduced. Further developments in the law of standing were founded upon the first limb of the test which confirmed the view that standing must depend upon some personal "stake" in the outcome of the litigation. ${ }^{29}$ This only begged the further question as to what kinds of interest would be sufficient. The second limb of the test was more enigmatic. It is proposed now to consider how the Federal courts applied the injury-standing limb of the test; secondly to examine the meaning and value of the "zone of interests" part of the test; and then to consider the most recent developments which have been designed to set new jurisdictional limits through an insistence that the injury complained of must not be too remote from the illegal conduct of the defendant.

\section{Injury in Fact}

It has been stated that "injury in fact" requires only that the plaintiff show that he has suffered some harm as a result of the defendant's allegedly unlawful conduct. ${ }^{30}$ The Supreme Court has confirmed this view by expressing approval of Davis' conclusion ${ }^{31}$ that any identifiable, even though only trifling, loss would satisfy the new standing formula. ${ }^{32}$ Naturally, according to this liberal

24. Approximately twenty five cases each year in the years immediately following the enactment of this provision:

25. Moreover the Supreme Court reasoned that the "legal interest" test was circular: "The legal interest test goes to the merits. The question of standing is different . .": 397 U.S. 150, 153 (1970).

26. 397 U.S. 150 (1970).

27. Ibid., at p. 152.

28. Ibid., at p. 153 .

29. Supra n. 19.

30. Vining, Legal Identity, at p. 29.

31. "Standing: Taxpayers and Others", 35 U. Chicago L. Rev. 601, 603 (1968).

32. U.S. v. SCRAP, 412 U.S. 669 (1973). 
interpretation, a variety of non-economic injuries will suffice, ${ }^{33}$ but it has been held that neither the possible risk of future injury, ${ }^{34}$ nor the mere exposure of the plaintiff to unlawful action without consequent loss will generate standing. ${ }^{35}$

The extent to which the "injury in fact" test had broadened the categories of individual entitled to come to court is demonstrated in the SCRAP case, ${ }^{36}$ which illustrates the willingness of the Supreme Court at that time to explore the very limits of the Art. III "cases" or "controversies" principle. SCRAP, the plaintiffs in this case, challenged a decision of the Inter-State Commerce Commission (I.C.C.) to impose a surcharge on railway freight. It was argued that this would augment reliance on non-recyclable goods which, in turn, would cause litter in the Washington Metropolitan area. SCRAP, an ad hoc environmental protection group, alleged that the I.C.C.'s decision had been reached without the preparation of the environmental impact statement required by statute. The group's interest in the matter was merely that it used the area in question for recreational purposes. There was no threat to anything which members of SCRAP owned, yet the Supreme Court held that such detriment as they suffered was sufficient to constitute "injury in fact". The use of the environment purely for recreation was an interest which the courts had jurisdiction to protect.

One interesting feature of the case is that the Court was not inhibited by the indirect nature of both the injury and the remedy awarded. For example, the Court could not be sure that the quashing of the I.C.C.'s decision would alleviate the grievance of SCRAP; that would be the responsibility of members of the public who used the area in question. Thus the Court did not require a guarantee that its intervention would redress the "injury in fact" upon which the standing of the Group was based. Subsequently, however, the Supreme Court has used the standing barrier in order to deny a claim where it could not positively be shown that the relief sought would provide a remedy for the complaint alleged. ${ }^{37}$

It is also interesting to note that the loss alleged by $S C R A P$ was shared in equal measure with other members of the community at large, thereby demonstrating that public values can be the concern of the individual litigant; indeed the case all but suggests that a "private attorney-general" can maintain an action to vindicate the public interest. This notwithstanding, it is also arguable that SCRAP is but an application of the "injury in fact" principle within the framework laid down by the Supreme Court in the Data Processing case. The concern expressed in the latter case that the antiquated "legal interest" test prohibited the protection of non-economic values, itself suggests the propriety of the concern of the members of SCRAP with the recreational interests which they shared with all other members 
of the community. However, in spite of the bold liberalization of standing achieved in SCRAP the courts were initially careful not to erode further the notion of "injury in fact". For example, in Sierra Club v. Morton ${ }^{38}$ an environmental protection organisation sought, on behalf of its members, to resist the commercial development of a site of great natural beauty adjacent to the Sequoia National Park. Without alleging that any of its members had suffered any harm as a result of the granting of permission to develop that site, the Club asserted that, by its nature, it had a special interest in the conservation and maintenance of national parks which would justify the court in awarding it standing to sue. However, the Supreme Court held that, since the pleadings did not reveal that any "injury in fact" had been suffered by the Club's members the action could not proceed in that form. A fortiori standing was denied in O'Shea v. Littleton $^{39}$ where the plaintiffs based their claim upon the rights of third parties who, they alleged, had been discriminated against on the grounds of their race and colour in the County's criminal justice system. The appellants had suffered no harm in their own private capacity and so the suit could not be maintained. Significantly, the invitation to treat the exposure of the plaintiffs to the illegal conduct of the defendant, without any further 'loss', as constituting "injury in fact", was not accepted by the Supreme Court recently in Allen v. Wright. ${ }^{40}$ As a result of these cases, it is manifest that the Supreme Court has been prepared to accept any concrete harm suffered in one's personal capacity as sufficient to generate standing to sue, but that loss suffered by third parties, or the mere exposure to unlawful conduct without any harm resulting in one's private capacity, will not suffice. Yet the promise of the Data Processing case has been fulfilled in so far as the courts will intervene to protect an individual whose interest in the matter was not purely economic, and thus the kinds of injury which will suffice for standing purposes would include the aesthetic, recreational and cultural interests upon which a high value is necessarily placed in a civilized society.

\section{The Second Limb of the Data Processing Test: the Zone of Interests, Protected or Regulated}

The interpretation placed on Art. III by the Supreme Court not only requires the plaintiff to demonstrate "injury in fact" but also that the interest he seeks to protect is ". . . arguably within the zone of interests to be protected or regulated by the statute or constitutional guarantee in question." ${ }^{41}$ Doubts have been expressed as to whether or not this provides any workable supplement to the "injury in fact" limb of the test. ${ }^{42}$ In the Data Processing case itself, Brennan and White JJ., who

40. Supra n. 35.

41. Association of Data Processing v. Camp 397 U.S. 150, 153 (1970).

42. Vining, Legal Identity, p. 104 el seq. 
delivered dissenting opinions as to the imposition of this second limb of the test, posed the following questions:

"What precisely must a plaintiff do to establish that the interest sought to be protected ... is arguably within the zone of interests to be protected or regulated by the statute? How specific an interest must he advance? Will a broad, general claim, such as a competitive interest suffice, or must he identify a specific legally protected interest? When, too, is his interest 'arguably' within the 'zone'? Does a mere allegation that it falls there suffice? If more than an allegation is required, is the plaintiff required to argue the merits? And what is the distinction between a 'protected' and a 'regulated' interest? Is it possible that a plaintiff may challenge agency action under a statute that unquestionably regulates the interests at stake, but that expressly excludes the plaintiff's class from the statutory beneficiaries." ${ }^{43}$

Brennan and White JJ concluded that the standing formula comprised merely "injury in fact".

The language of the second limb (the zone of interests protected or regulated) suggests that the constitutional guarantee in question must intentionally set out to protect or regulate the interest advanced by the plaintiff before he can have standing to sue. Thus, the intention of the legislature in enacting a particular measure is directly at issue. In the United States this has been criticised as unsatisfactory and, ultimately, unworkable. A leading commentator ${ }^{44}$ has stated that the "statutory beneficiary" inquiry detracts from the central issue, which is determination of harm for the purpose of invoking the judicial role. If the individual has suffered such harm, then he will have suffered "injury in fact" and, by itself, that would satisfy Art. III.

The problems inherent in the notion of the "statutory beneficiary" have been judicially recognised, and it may be that this limb of the Data Processing test is no longer regarded as helpful in any standing inquiry. Significantly, in Duke Power v. Carolina Environmental Study Group ${ }^{45}$ the Supreme Court established that the Constitutional requirements for standing were that the appellant should have suffered "injury in fact" and, additionally, that there should be a causal connection between the injury alleged to have been suffered and the challenged conduct. One commentator has observed that the failure even to note the second limb of the Data Processing test is "as much a reflection of its irrelevance as its desuetude."

It is likely that the second limb of the Data Processing test has been abandoned. Henceforward, the approach adopted in Duke Power is probably to be regarded as

43. 397 U.S. $150,177$.

44. Supra n. 42.

45. 98 S.Ct. 2620 (1978).

46. 92 Harv. L. Rev. 253, 261. As Ely states, it is difficult to justify the "zone of interests" limb of the test since, in constitutional matters such as the due process guarantee, all citizens of the United States might arguably be within the zone of interests to be protected. This limb of the test is almost meaningless in such matters. 
authoritative. The plaintiff will have standing if his "injury in fact" is sufficiently proximate to the challenged conduct.

\section{The Causation Requirement}

In a series of cases the Supreme Court appeared to resile from the liberal attitude that it had adopted in the SCRAP case. ${ }^{47}$ It had been noted with concern, even in SCRAP itself, that the Court had been asked to follow "an attenuated line of causation to the eventual injury", 48 quite apart from the fact that the "injury in fact" rule had been so undermined that "any identifiable trifle" could constitute a legally cognizable injury. ${ }^{49}$ As a result, a renewed search for jurisdiction limitation was begun based upon the concept of remoteness of injury.

In Warth v. Seldin ${ }^{50}$ it was decided that remoteness involves two related ideas; first, that the plaintiff must show directness of injury and, secondly, redressibility of injury in so far as the relief sought will remove the harm of which the plaintiff complains. ${ }^{51}$ The directness of injury requirement is a valid one because, in highlighting the defendant's factual responsibility for the plaintiff's injury, the rule ensures that the proper defendant is identified in the suit. The redressibility requirement is thought to emanate from a rule of constitutional law that the court will have no jurisdiction to pronounce upon the matter if its judgment will not affect the controversy between the parties. However, it can be argued that those two requirements have been misapplied or not applied at all.

One issue to be resolved was whether these twin causation requirements would prohibit the award of standing to a litigant whose injury was only inflicted indirectly, as, for example, had been the case in SCRAP..$^{52}$ As mentioned above, the members of SCRAP would have had difficulty in establishing that the possibility of an increase in litter in the environment would be eradicated by the Court's intervention in that case. Thus a redressibility requirement, strictly applied, could exclude all claims based upon "injury in fact" inflicted only indirectly. However, although in Linda R.S. v. Richard D. ${ }^{53}$ the Court declined to award standing to the appellant in these circumstances, a less restrictive attitude now seems to have gained ground. The redressibility requirement, for example, can be satisfied if there is a likelihood, ${ }^{54}$ or perhaps a substantial likelihood, ${ }^{55}$ that the relief sought will redress the plaintiff's injury. Similarly, the plaintiff's injury

47. Warth v. Seldin 422 U.S. 490 (1975); Linda R.S. v. Richard D. 410 U.S. 614 (1975); Siman v. Easterm Kentucky Welfare Rights Organization 426 U.S. (1976); and lately, Allen v. Wright 104 S. C. 3315 (1984). 48. 412 U.S. 669, 688 (1973), per Stewart J.

49. Ibid., at p. 689 n. 14.

50. Supra n. 37.

51. Whether the relief sought must, if granted, inevitably redress the injury has been a controversial matter and is discussed below.

52. Supra n. 32.

53. 410 U.S. 614 (1975).

54. Allen v. Wright, supra n. 47 , at p. 3325.

55. Duke Power v. Carolina Environmental Study Group 438 U.S. 59. 
need only be "fairly traceable" to the defendant's conduct. ${ }^{56}$ Thus formulated, the twin causation requirements seem to embrace "injury in fact" inflicted indirectly, and standing has been awarded in these circumstances notwithstanding the decision in Linda R.S. v. Richard D. ${ }^{57}$ Nonetheless, there remains a hesitancy to award standing in these circumstances and this has deprived some would-be litigants of access to court. Even in cases in which there has been certainty as to the standards to be applied, the results seem to defy a coherent exposition.

Simon v. Eastern Kentucky Welfare Rights Organisation ${ }^{58}$ illustrates the confusion which clouds the causation issue. Here standing was ostensibly denied because the plaintiffs could not show directness of injury. The action was brought by a financially disadvantaged class who sought to challenge a policy of the Internal Revenue Service which conferred a favourable tax status on hospitals which treated poor people only in emergency cases. On behalf of the class it was argued that this policy decision encouraged discrimination in the provision of hospital care against less well-off citizens in violation of their Constitutional rights.

Standing was denied because the Supreme Court, although apparently paying lip-service to the notion that standing could be awarded to those suffering only an indirect injury, rejected the argument that the quashing of the Internal Revenue Service's policy would remove the incentive to discriminate, thereby providing an indirect remedy for the injury suffered. This argument was dismissed as being "speculative". ${ }^{59}$ However, it is not unreasonable to assume that individuals will respond to tax incentives; indeed the purpose of granting such an incentive is to promote the activity in question, and the removal of that incentive, by the same token, may discourage it. Hence, in contrast to its decision in SCRAP, the Supreme Court now seemed willing to intervene only where it would be certain that the granting of relief would alleviate the "injury in fact" upon which the claim was brought. Normally, this would be in cases of injury inflicted directly. However, in other cases where the Court seems to have been willing to consider the merits the causation requirement has been applied in a less rigorous manner, and standing has been awarded in respect of "injury in fact" inflicted indirectly upon the plaintiffs.

This was particularly so in Duke Power v. Carolina Environmental Study Group. ${ }^{60}$ In this case an environmental protection group challenged the validity of a Federal statute, the Price-Anderson Act, which limited the amount of damages which could be recovered against companies licensed to operate nuclear power stations in the event of a nuclear accident. The Act has been passed in order to make the development of the nuclear industry more attractive to investors. The group

56. Simon v. Eastem Kentucky Welfare Rights Organization and Allen v. Wright, supra n. 47.

57. E.g., Duke Power v. Carolina Environmental Study Group, supra n. 55, and Regents of the University of Califormia v. Bakke, infra n. 61.

58. 426 U.S. 26 (1976).

59. Ibid., at pp. $43-44$.

60. 98 S. Ct. 2620 (1978). 
alleged that two nuclear plants, which were in the process of being constructed, would cause low-level radiation, thereby affecting the water temperature and wildlife in nearby lakes. Had Simon been followed, the group would have had difficulty in establishing redressibility since it was unlikely that it could demonstrate that the low level radiation problems were "fairly traceable" to the Price-Anderson Act. Similarly it would have been difficult to prove that there was a substantial likelihood that the quashing of the Act would cure those problems. The nuclear power stations were already partially constructed and, in view of the substantial commitment of funds already made, it was unlikely that the companies would dismantle the power stations simply because the limit on liability for nuclear accidents had been removed.

However, the Court held that the group had standing to sue. Reliance was placed upon evidence which showed that the companies would not have become involved in the nuclear industry without the safeguards of the Price-Anderson Act. The Act was therefore held to have encouraged the growth of the nuclear industry and it was this which forged the necessary causative link between the "injury in fact" and the challenged provision. This being so, it is not easy to understand how in Simon the granting of tax concessions to private hospitals, whose medical fees excluded poor patients, did not encourage the hospitals to maintain their activities. The two decisions seem difficult, if not impossible, to reconcile.

However, perhaps the most interesting comparison is that between Warth v. Seldin ${ }^{61}$ and Regents of the University of Califormia v. Bakke. ${ }^{62}$ In the former case various litigants challenged a city zoning or planning ordinance which, they alleged, prevented the construction of cheaper housing in the City of Penfield. It was argued that this violated the Constitutional rights ${ }^{63}$ of the poor since the ordinance would have the effect of denying them access to homes in the City. However, those litigants who based their challenge on the ground that, enjoying only a low or moderate income themselves, the ordinance injured them personally, failed to show that their injury would be redressed by the intervention of the court. House prices were regulated by market forces which, it was held, were beyond judicial influence.

However, the market forces argument cannot logically dispose of the case. Just as house prices may have been the product of market forces, so were incomes, and it is reasonable to suppose that, in fixing wages, account would have been taken of the local housing costs. Naturally, those on low or moderate income would then, presumably, have been able to afford the cheaper property had it been available. The plaintiff's argument was that such housing was not to be constructed by virtue of the zoning ordinance, and it was that legislation, and not market forces, which excluded these litigants from the Penfield area. On the facts, it is therefore argued

61. Supra n. 37.

62. 438 U.S. 265 (1978).

63. As well as rights under the Civil Rights Statute 42 U.S.C.S. C.L. 1981-1983. 
that the "substantial likelihood" test for redressibility was satisfied as far as these litigants were concerned, and that therefore they should have been awarded standing to sue.

In Bakke's case standing was awarded on legally similar facts. Broadly, a white male applicant was denied a place at a medical school which, in respect of a number of its places, discriminated in favour of minority groups. Bakke's academic record was more distinguished than some admitted under this programme and so he alleged that his exclusion violated his Constitutional rights. However, he faced the same difficulty concerning the redressibility requirement that had proved fatal to the claims in Warth v. Seldin. Even if the Court declared the admissions policy to be unlawful, Bakke would not necessarily be admitted to the school. Access would still be regulated by the school itself, just as access to Penfield in Warth v. Seldin was considered to have depended upon extraneous market forces: both were outside the control of the court.

The Supreme Court responded by re-examining Bakke's injury. It was held that, in truth, his injury was the loss of opportunity to compete for all the places in the school by virtue of the challenged admissions' policy. Of course, had a similar approach been adopted in Warth v. Seldin some of the plaintiffs might also have been awarded standing to sue. After all, they had been denied the right to compete for the more modest property which would have been available in Penfield in the absence of the zoning ordinance. Arguably these two decisions are also incapable of reconciliation.

In conclusion, it seems that although the Supreme Court has accepted the principle that injury inflicted indirectly may be cognizable, the decisions betray an obvious lack of coherence. The re-definition of Bakke's injury makes a nonsense of the decision in Warth v. Seldin. This haphazard approach has led to judicial doubts as to whether the causation principle is not employed merely as a camouflage for the court's aversion to the plaintiff's claim. ${ }^{64}$ In considering the causation issue, the problem no longer seems to be the formulation of an appropriate test, but rather, in the light of value judgments which appear to have crept into these recent decisions, of ensuring its consistent application.

This haphazard application of the causation rules, allowing the court to award standing in some cases, but not in others which are legally indistinguishable, highlights a continuing, deep-seated, confusion affecting the most basic jurisdictional issues. Therefore, in spite of the recent attempts to formulate definitive principles regulating the standing inquiry, the most fundamental questions seem to remain unresolved: What kinds of dispute are amenable to judicial settlement? What kinds of grievance entitle an individual to invoke the aid of the court? Have any new solutions to these questions been postulated? 


\section{The Future of the Injury-Standing Principle}

The law is still in a transitional stage and the answers to the above questions have not been found. Recently, however, there have been signs that possible future developments in the law of standing may be based upon a radical re-appraisal of Art. III which might result in the abandonment of the whole "injury-standing" philosophy. At present this attenuated line of authority is confined to particular circumstances which are thought to be exceptional and only of limited application. But if ever an exception were likely to undermine the general rule, these cases show such a potential since their rationale is precisely that Art. III does not require the individual litigant necessarily to demonstrate any personal interest in the outcome of the suit.

It has been stated that Art. III does not, of itself, require that the judicial role be confined to the settlement of disputes between self-interested parties. ${ }^{65}$ That is a limitation which the courts have placed upon themselves, but which has, in the past, been thought to emanate from Art. III. It has been argued that the "cases" or "controversies" principle merely seeks to entrench the adversarial nature of the judicial process. ${ }^{66}$ At the heart of this is the notion that the courts depend primarily upon full argument provided by the parties. In order that a just settlement can be reached, each must put forward every view which could be seriously advanced in support of his own case. This has been dubbed "vigorous advocacy" by one party of his own rights. ${ }^{67}$ However, the quality of "vigorous advocacy", it is now thought, can exist without the plaintiff having any personal interest in the outcome of the litigation; in other words the plaintiff's challenge may be based upon third party rights, because the former may be in a position to advance that cause as effectively as the right-holders themselves. Access to court then becomes a question of fact namely whether the challenger can advance every point which might have been made by the right-holders themselves. As will be indicated, the most important consideration is the 'proximity' of the relationship between the challenger and the right-holder.

The origins of this view are of respectable antiquity in Federal jurisprudence, and are echoed even in our own law. ${ }^{68}$ An early statement in Federal law appears in Holden v. Hardy, ${ }^{69}$ in which a State statute prevented employees in the mining industry from working in excess of eight hours each day. A mine owner argued that the statute violated the equal protection clause of the Federal Constitution in so far as it inflicted particular hardship on his employees and removed from them the right to labour as long as they pleased. The Supreme Court, in doubting his right to base his challenge upon the loss suffered by third partics, stated: "[His]

65. U.S. Parole Commissioner v. Geraghty 100 S. Ct. 1202 (1980).

66. This has been accepted for a considerable period. Hitherto, however, only the plaintiff's cognizable interest guaranteed adversity: Baker v. Carr 3669 U.S. 186 (1962), and O'Shea v. Litlleton 414 L.S. 488 (1974).

67. See, e.g., U.S. Parole Commissioner v. Geraghty, supra n. 65.

68. Fohn v. Rees [1969] 2 All E.R. 274, 282, per Megarry J.

69. 18 S. Ct. 383 (1898). 
argument would certainly come with better grace and greater cogency from his workers." 70

"Vigorous advocacy" by the mine owner of the rights of the employees was not likely in this case since they did not enjoy similar interests in the action. Clearly the de-regulation of the working hours in mines might lead to exploitation of the miners by the owners, and thus it was likely that the employees would have wished to resist de-regulation. Hence, the litigation of the third party rights in this case could not proceed.

However, in U.S. Parole Commissioner v. Geraghty, ${ }^{71}$ the Supreme Court did hear an appellant who lacked any interest in the suit in the traditional sense. The case concerned a prisoner who, whilst still in custody, sought to challenge the validity of parole release guidelines on behalf of himself and others similarly affected by them. During the course of the suit however, he was released from prison, and so lost his personal interest in the suit. It is settled law that he could have continued to represent the class, in spite of his own lack of a personal interest, if he obtained a certificate from the District Court that his action was properly framed.$^{72}$ This had, however, been denied to him. He wished to appeal against the ruling of the District Court, but found himself in the impossible position of not having a cognisable injury in the suit and thus being unable to invoke the aid of the court even by way of appeal from the denial of certification.

The Supreme Court approached the difficulty by examining again the fundamental purposes of the Art. III "cases" or "controversies" principle. At one level the resulting opinion appears to accept the orthodox view that "the imperatives of a dispute capable of judicial resolution are sharply presented issues in a concrete factual setting, and self-interested parties vigorously advocating opposing positions." ${ }^{73}$ However, in spite of the apparent emphasis placed upon the need for self-interest as an "imperative" of the court's jurisdiction, the Supreme Court awarded standing to the plaintiff in this case notwithstanding his lack of a personal interest in the outcome of the suit.

The crucial finding was that the plaintiff remained a "vigorous advocate" of the class members' interests who were still affected by the parole guidelines in question. Whilst "vigorous advocacy" may depend upon the advancement by the plaintiff of a personal interest in the suit, the notion embraces cases in which a non-interested litigant appears before the court. The initiative in this case is thus the divorce of "injury in fact" from the Art. III "cases" or "controversies" principle where effective advocacy can be provided by other means.

In determining whether a litigant can provide vigorous advocacy when seeking to litigate third party rights, two considerations seem to assume a greater

72. The certificate is available under Federal Rule of Civil Procedure 23. An example of its use appears in Sosna v. Lowa 419 U.S. 393 (1975).

73. 100 S. Ct. 1202, 1212 (1980). 
importance than all others, and it is these which have allowed the courts to justify this form of litigation as an exception to the general principles of standing. First, there must be a close relationship between the litigant and the third party right-holders; second, the right-holders must find some difficulty in enforcing their own rights, although, as will be seen, in practice little weight seems to be attached to this latter principle. Singleton $\mathrm{v}$. Wulff ${ }^{74}$ provides a typical illustration of this type of litigation. Two licensed physicians challenged the constitutional validity of a statute restricting the availability of abortion treatment under the Medicaid Programme on the grounds that it violated the Constitutional rights of their female patients. The Court, finding that the doctor/patient relationship was a relationship of confidence, and also that women who might otherwise wish to enforce their own Constitutional rights would encounter problems ${ }^{75}$ which would inhibit their willingness to come to court, allowed the challenge by the physicians. Since, it was held, a woman relied upon the doctor to perform any abortion, the interests of both in this challenge could be regarded almost as synonymous. It was stated that "there seems little loss in terms of effective advocacy from allowing the assertion of [the patients' rights] by a physician." "76 As was stated in Holden v. Hardy, ${ }^{77}$ the convergence of interests enjoyed by the right-holders and the challenger is a necessary safeguard for the former, since the challenger will then be able zealously to present their mutual interest in the case, and the principle of res judicata could not then prejudice the right-holders.

Relationships of sufficient mutuality have been held to include that between teacher/pupil and parent, ${ }^{78}$ and somewhat controversially, in Carey v. Population Services International, ${ }^{79}$ between vendor and purchaser in a case which concerned the regulation of the marketing of contraceptives. If the latter case is a correct exposition of the law it might not be unreasonable to take the view that the interests of the environmental protection group and the owners of the land threatened with pollution in $S C R A P$ converged to the extent that litter pollution would almost certainly have been opposed by both. It might therefore have been conceivable that there was no injustice done in hearing only the members of $S C R A P$ and not the right-holders, since the former could supply the same

74. 96 S. Ct. 2868 (1976).

75. The Court identified "mootness" as the first difficulty encountered (see n. 14 supra). Secondly, it was felt that a woman might be deterred by considerations of privacy. Significantly, the Court admitted that both of these considerations might easily be overcome. Mootness could be avoided by the application of the "capable of repetition, yet evading review" principle (n.14 supra); and the litigation could proceed anonymously as, e.g., in Roe v. Wade (supra n. 14). Thus, the justification for allowing a claim by a non-interested party based upon the supposed difficulty that the right-holders would encounter if enforcing their own rights is somewhat tenuous, and could be regarded as a scarcely veiled attack upon the general injury-standing principle itself.

76. Singleton v. Wulff, supra n. 74 , at p. 2876.

77. Supra n. 69.

78. Pierce v. Society of Sisters 268 U.S. 510 (1925).

79. 97 S. Ct. 2010 (1977). 
"vigorous advocacy" as the right-holder themselves if they had instituted proceedings.

However, in spite of the broadening of the exceptions to the "injury-standing" philosophy, the Supreme Court in Allen v. Wright ${ }^{80}$ emphatically resisted its abandonment. "Injury in fact" suffered by the plaintiff is, it was held, of "constitutional significance" and necessarily inherent in Art. III since it was the purpose of that Article to foster the separation of powers within the Constitution. The judicial branch has no power to decide upon "abstract" issues which fell within the preserve of the representative branches of the State. The judicial power was confined to "specific" matters in which each party had an identifiable stake in the outcome. Doubt has therefore been cast upon the propriety of a re-interpretation of Art. III based upon Geraghty's case, ${ }^{81}$ and it is probably unlikely that any fundamental developments in standing are imminent. However, it is important to note that where the court is willing to consider the merits, the matter may well be held to fall within one of the exceptions to the ordinary standing principles. Although one purportedly rests upon the narrow grounds that the plaintiff must share a close relationship with the right-holders and that the latter must have some difficulty in enforcing their own rights, the exception is in fact very much more expansive than this formulation suggests. Its breadth was revealed by the Supreme Court when it held that the relationship of vendor and consumer may fall within its parameters, ${ }^{82}$ in a decision which goes far beyond what had hitherto been acceptable. As a result of this case, the precise limits of this exception category must be in considerable doubt, and its further expansion could, by itself, threaten the orthodox rules of standing based upon "injury in fact". It is now arguable that the continued broadening of the categories of relationship which justify a departure from the orthodox standing principles, coupled with the questions surrounding the true rationale of Art. III, may ultimately lead to an erosion of the injury-standing principle.

\section{Conclusion}

The doctrine of locus standi, in its outmoded proprietorial mould, served to exclude the public spirited litigant who stepped forward to challenge unlawful public action in a matter in which he had no legally cognizable interest. Consequently, where the Attorney-General refused to act, the courts were forced to wait upon a challenge by a member of a possibly small class of those who had suffered the kind of injury which the court would recognise. Although, perhaps, the greatest incentive to come to court lay with those affected by the unlawful public action in question, increasingly, those who have wished to do so have been motivated by reasons other than the protection of a personal right or interest of their own. However, under the traditional doctrine of standing, the court has declined to hear the public spirited

80. 104 S. Ct. 3315 (1984).

81. Supra n. 65.

82. Supra n. 79. 
litigant who lacks a recognized interest in the outcome of the suit, no matter how meritorious the substance of his case. ${ }^{83}$

In both English law and United States Federal law recent developments have sought to strike an appropriate balance between instituting an actio popularis on the one hand, and enforcing a rigorous doctrine of standing which would inevitably disqualify the meritorious but otherwise unqualified litigant on the other. For Lord Denning the matter was clear: the court should entertain causes brought bona fide by an individual who could demonstrate a prima facie case that a public authority had breached its public duty. This was the tenor of his judgment in the Peachey-Property case, ${ }^{84}$ and it was a theme which he re-iterated in the Blackbum cases. ${ }^{85}$ The House of Lords appears to have been persuaded by the pragmatism of such an approach in I.R.C. v. National Federation of Self-Employed and Small Businesses $L t d .{ }^{86}$ in which it envisaged circumstances in which a litigant, otherwise lacking a sufficient interest, might nonetheless have standing to sue. ${ }^{87}$

Equally, the Supreme Court in the Data Processing case seems to have recognised the prevalence of the public policy considerations weighing upon the standing doctrine. It released the doctrine from its proprietorial chains, but retained the need for the plaintiff to show some detriment in his private capacity. It continued to expand the categories of person entitled to sue in SCRAP, in which non-economic values were held to constitute "injury in fact", and standing was awarded even though the loss was inflicted only indirectly. Data Processing and $S C R A P$ mark significant progress towards a comprehensive system of administrative law in the United States. It is lamentable, however, that the causation principle has been employed subsequently in such an arbitrary manner. The suspicion perhaps cannot be avoided that the denial of standing to litigants such as those in Warth v. Seldin was predicated upon covert policy reasons which, if disclosed, would perhaps reveal a judicial aversion to the merits of the plaintiff's case.

Parallel developments in areas generally regarded as justifying a special treatment outside the ordinary standing rules continue to indicate the need for a certain flexibility in the application of the general principle itself. In order to avoid the inconvenience of the normal rules the Supreme Court has loosened the confines of the exceptional categories, and has justified its decision to do so by questioning the long accepted orthodoxy that Art. III entrenches the injury-standing principle as part of the Federal Constitution. Moreover the continued broadening of the categories of those entitled to circumvent the "injury in fact" requirement may cause the eventual atrophy of the injury-standing

83. E.g., Gouriet v. Union of Post Office Worken [1978] A.C. 435

84. [1966] 1 Q.B. $380,400$.

85. R. v. Commissianer of Police of the Metropolis [1968] 2 Q.B. 118; Blackburn v. Attomey-General [1971] 1 W.L.R. 1037; R. v. Police Commissioner, ex p. Blackburm [1973] Q.B. 241; R. v. Greater London Council, exp. Blackbum [1976] 1 W.L.R. 550.

86. [1982] A.C. 617 .

87. Ibid., per Lord Wilberforce at p. 633; Lord Fraser at p. 647; Lord Roskill at p. 662. 
principle. But, even then, there will be a need for jurisdictional limitations; for, as Lord Denning said in the Peachey Property case, ${ }^{88}$ a 'busybody' should not be entitled as of right to invoke the judicial process. Whether or not the United States courts would be able to hold that such a person could not provide "vigorous advocacy" has yet to be decided. However, notwithstanding the valuable work already undertaken by the Supreme Court, when the courts come to examine these issues the questions to be resolved will be the fundamentally perennial ones: Which types of dispute are suited to judical resolution? and When is an individual entitled to invoke the judicial process? These will always remain the raw issues of the standing question, and perhaps it is not desirable that one solution, fixed for all time, should ever be realized; for each generation should be free to choose the values which its society will cherish and to decide how these values will be protected. 